This is the author's Post-print version (final draft post-refereeing as accepted for publication by the journal). The definitive, peer-reviewed and edited version of this article is published as: Feng Z., Boyle P., van Ham M. \& Raab R. (2012) Are mixed ethnic unions more likely to dissolve than co-ethnic unions? New evidence from Britain. European Journal of Population 28(2), 159-176.

http://dx.doi.org/10.1007/s10680-012-9259-0

\title{
Are mixed ethnic unions more likely to dissolve than co-ethnic unions? New evidence from Britain
}

\section{Zhiqiang Feng • Paul Boyle • Maarten van Ham • Gillian M. Raab}

\author{
Z. Feng \& P. Boyle \& G. M. Raab \\ Longitudinal Studies Centre-Scotland (LSCS), School of Geography \& Geosciences, \\ University of St Andrews, St Andrews KY16 9AL, UK \\ e-mail: zhiqiang.feng@st-andrews.ac.uk
}

P. Boyle: e-mail: p.boyle@st-andrews.ac.uk

G. M. Raab: e-mail: g.raab@st-andrews.ac.uk

M. van Ham

OTB Research Institute for the Built Environment, Delft University of Technology, P.O. Box 5030, 2600 GA Delft, The Netherlands \& University of St Andrews e-mail: $\underline{\text { m.vanham@tudelft.nl }}$

\begin{abstract}
The increasing proportion of ethnic minorities in Britain has been paralleled by an increase in the occurrence of mixed ethnic marriages between one White partner and an ethnic minority partner. Such marriages are thought to be at higher risk of divorce, but empirical studies so far have been inconclusive. This paper uses the Office for National Statistics longitudinal study for England and Wales to investigate whether mixed ethnic unions are more likely to end in divorce than co-ethnic unions. We followed married couples in 1991 to 2001 and examined their risks of divorce. We found evidence that mixed ethnic unions have a higher risk of dissolution than co-ethnic unions. However, after controlling for partners' characteristics, most importantly the younger ages of people in mixed ethnic unions, the risk of divorce for mixed ethnic unions was no longer elevated, but lay close to the higher risk found for the two constituent co-ethnic unions.
\end{abstract}

Keywords: mixed ethnic unions; longitudinal study; divorce; convergence theory; heterogamy effect

\section{Introduction}

The rise in the proportion of ethnic minorities is one of the most marked demographic changes in Western countries in the last few decades (Coleman 2009). In England, for 
example, the percentage of ethnic minorities increased from $4.6 \%$ to $8.6 \%$ between 1981 and 2001 (Rees and Butt 2004). This change has led to concerns about the socio-economic, cultural, and spatial integration of minority groups and some minority groups are more geographically segregated from mainstream society than others (Finney and Simpson 2003; Rees and Butt 2004). Mixed ethnic unions, particularly between Whites and non-Whites, are generally regarded as an important indicator of minority integration in their host societies. The growth of mixed ethnic partnerships illustrates increasing mutual acceptance of ethnic groups; indeed, it can be argued that mixed partnerships represent the ultimate in social acceptability and assimilation (Bratter and King 2008; Schoen and Cohen 1980; Tolsma et al. 2008; van Ham and Tammaru, 2011). It is therefore a positive sign that there has been a considerable rise in mixed ethnic unions, both in their absolute numbers and their proportion of all unions in Britain, over the last few decades (Berrington 1996; Coleman 2004; Feng et al. 2010; Muttarak 2004). However, this increase in mixed ethnic unions has been the subject of negative comments from the public, politicians, the press and academics and they have not always been celebrated. Instead, mixed ethnic unions have frequently been seen as a social problem, which lead to difficulties for the partners, their children and the people around them (Benson 1981).

Recent years have seen an increase in research on the basic patterns and trends in the growth of mixed-ethnic unions in Britain (e.g. Ballard 1997; Berrington 1996; Coleman 1985; 2004; Data Management and Analysis Group Update 2005; Holdsworth and Dale 1997; Johnston et al. 2006; Model and Fisher 2002; Muttarak 2003; 2004). However, none of the studies focuses specifically on the dissolution of mixed ethnic unions. There has been a significant rise in the rates of union dissolution in western countries in the post-war period; in Britain the crude divorce rate increased more than 6 fold from 2 per 1000 in 1960 to about 13 per 1000 marriages in 2000 (Chan and Halpin 2003). This trend has largely been attributed to the increase in the economic independence of women, changes in public attitudes toward divorce, and the liberalisation of marriage legislation (Becker 1981; Kierman and Meuller 1999; Thornton 1989; Trent and South 1989). Certain factors, such as getting married at a young age and premarital birth, are positively associated with dissolution, while higher income couples and those with higher qualifications have a lower risk of divorce (Chan and Halpin 2003; Kierian and Meuller 1999; Teachman 2002). Ethnicity is also associated with the risk of separation; studies from both the US and Britain find that Black populations have higher risks of divorce than Whites, while Asians usually have lower risks (Berrington 1996; Fu 2006; Heaton and Albrecht 1991; Teachman 2002). However, studies on union dissolution have generally ignored the effects of ethnic mixing in households. The existing evidence is inconclusive with some studies suggesting an elevated risk of divorce for mixed ethnic couples (Dribe and Lundh, 2011; Kalmijn et al. 2005) and others finding no such evidence (Cuningham 1990; Jones 1996; Zhang and van Hook 2009).

It might be expected that heterogamous partnerships would be more likely to dissolve than homogamous partnerships. Cultural characteristics relating to tastes, values, ambitions and communication styles vary across ethnic groups (Kalmijn et al. 2005). Other factors include societal attitudes and the (perceived) support that partners in mixed ethnic couples may or may not receive. Mixed couples may not receive as much support from their social networks as those who conform to more conventional partnership arrangements. We might imagine that these issues may have become less important over time, as couples from mixed ethnic backgrounds become more common and accepted.

This is the first study to investigate the dissolution of mixed ethnic couples using large-scale longitudinal data from the England and Wales Office for National Statistics Longitudinal Study (ONS-LS). Here, we define mixed ethnic marriages as opposite-sex married couples that include a White person and a Black or an Asian partner. We compare 
the risk of dissolution for different types of mixed couples with that for co-ethnic couples. This study complements those that describe the pattern and formation of mixed ethnic unions, and this aspect extends our understanding of the integration of minorities in Britain. (Kalmijn 1998).

\section{Theoretical background}

Two competing theories have guided research on the instability of mixed ethnic unions (Jones 1996; Kalmijn 1998; Zhang and van Hook 2009). The first theory starts from the observation that homogamy is the norm while heterogamy is aberrant (Kalmijn et al. 2005). It is well know that people tend to choose partners with similar age, religious, ethnic, educational, and family characteristics (Kalmijn 1991; Kalmijn 1998; Schoen and Weinick 1993). Individual preferences underpin such partner choices, and people choose partners with similar characteristics because they are more likely to have similar values, tastes, and behaviours, including views on issues such as gender roles, division of labour in the household and the upbringing of children.

The opportunity structure of suitable partners also plays an important role in partner choice. The chance of meeting someone with similar characteristics is generally higher than that of meeting someone with different characteristics as most people meet potential partners at school, at work, at a friend's home, or in the neighbourhood (Houston et al. 2005). Since residential areas and workplaces tend to be segregated by ethnicity it is more likely that people will socialize with those from groups similar to themselves (Ellis et al. 2004).

Partner choice is also influenced by the opinions of family members and members of one's social circle. The role played by parents or other family members in partner choice varies for different cultures. But, in most cultures, a homogamous relationship is more likely to meet with the approval of families, relatives and friends as the partner is more likely to resemble them and may seem to fit more easily into their social networks.

The advantages that can be identified for homogamous unions might in turn translate into the disadvantages of heterogamous unions. Partners in mixed ethnic couples are more likely to differ in values, life styles and norms, which may make it difficult for them to reach consensus in daily life decisions (Bumpass and Sweet 1972; Kalmijn et al. 2005). Such disagreements may induce stress and could be associated with the risk of divorce. If, in addition, the support from peers and family is less strong for those in mixed ethnic couples, the risk of divorce may raise further. However, it can also be argued that mixed ethnic couples have thought through all possible adverse aspects before forming a partnership and believe their love to be strong enough to overcome the disadvantages (Blau and Schwartz 1984). This would imply that mixed ethnic unions do not have to be less stable than co-ethnic unions.

The alternative theory to the homogamy perspective is the ethnic convergence theory. This theory expects that the likelihood of divorce of a mixed ethnic marriage falls between those of the two ethnic groups involved (Jones 1996). It is already well-known that divorce risks differ between ethnic groups and therefore we might expect the ethnic composition of the mixed ethnic union to influence the stability of the partnership before we even consider the potential additional strains that might be related to living in a mixed union. Different ethnic groups have different cultures and traditions regarding marriage and divorce. Some groups have more 'modern' values and be more tolerant to divorce, while others with more 'traditional' values may be more opposed to divorce as a response to union disharmony, even in circumstances when the partnership quality is low (Berthoud 2000; Heaton and Albrecht 1991; Jones 1994). We might expect that the divorce behaviour of partners from different ethnic groups will be inherited from their individual backgrounds. For example, couples 
consisting of two partners from the White group have higher divorce rates than couples consisting of two partners from the Asian group (Berthoud 2000). According to the ethnic convergence theory we expect that Asian-White marriages will be less likely to dissolve than White-White marriages but more likely to dissolve than Asian-Asian unions.

\section{Empirical studies}

Most existing studies on the dissolution of mixed ethnic marriages are descriptive and base on their conclusions on the ratio of the number of divorces to marriages in the same or adjacent years. However, their findings are inconsistent. For example, Monahan (1970) used marriage registration data over a period of 30 years in Iowa and found that although BlackBlack marriages displayed higher rates of divorce than White-White marriages, mixed marriages between Black husbands and White wives were more stable than those between White couples. Tribalat (1987) showed that in the Federal Republic of Germany only marriages between German women and Turkish or Yugoslav men displayed higher rates of divorce than other co-ethnic marriages and mixed ethnic marriages. In California, Maneker and Rankin (1988) found that the divorce propensity was higher only in marriages between Black men and White women. Schwertfeger (1982) was the first to use panel data, following a 1968 cohort of first marriages among residents in Hawaii to 1976. Schwertfeger did not find clear patterns in divorce rates for mixed ethnic couples apart from a high level of stability for Chinese co-ethnic unions. On the other hand, Heaton's (2002) US study of mixed marriages between Blacks and Whites reported that marital dissolution was more likely for mixed ethnic couples. Kalmijn et al. (2005), using linked marriage and divorce registration data from 1974 to1994 in the Netherlands, found a high risk of dissolution for couples including a Dutch person and someone from another nationality. Zhang and van Hook (2009) used six panels of the US Survey of Income and Program Participation to examine the likelihood of dissolution of interracial marriages and found no homogamy effect. Instead they found dissolution propensities of interethnic unions to fall between the propensities of the component ethnic groups. Dribe and Lundh (2011) recently explored the relationship between heterogamy and union dissolution using population register data in Sweden. They used event history models and found that mixed ethnic unions exhibited higher risks than co-ethnic unions.

\section{Data and methods}

The data used for our analyses are drawn from the ONS-LS, which is a nationally representative 1\% sample of the English and Welsh population including approximately 500,000 people. Anyone whose birthdate falls into one of the four selected dates is included in the study. The study links information from the 1971, 1981, 1991 and 2001 Censuses and the sample is updated through inter-censal births, deaths, immigrations, embarkations and reentries. Information on the household members of ONS-LS members is also included, although the records for these individuals are not linked through time. In addition to census data, information is linked from cancer and vital events registrations. For example, information on live and still births to sample mothers, infant deaths to sample mothers, and deaths of sample members' spouses is added to the data. Marriage and divorce registrations are not linked to sample members. Therefore we did not have information on age at marriage or duration of the marriage (Hattersley and Creeser 1995).

We extracted 1991 and 2001 census data from the ONS-LS. The 1991 Census ethnic groups were aggregated into five broad categories to avoid groups with small numbers of mixed ethnic unions (Table 1). The 'Other' ethnic group is highly heterogeneous and we 
therefore excluded this group from our analysis, leaving four groups: White, Black, South Asian, and Other Asian. As couples from two minority groups are rare, our definition of a mixed ethnic union therefore involved a White partner and a partner from one of our three ethnic minority groups.

\section{<Table 11991 ethnicity definitions>}

We excluded cohabiting couples and thus our sample includes all male-female couples who were married in 1991 and where the sample member was also present in the 2001 Census. We also identified partners of LS members in 2001 in order to identify couples who divorced between 1991 and 2001 and those that stayed intact. In total there were 172,473 couples in our data, of whom $12 \%$ divorced between 1991 and 2001. Fewer than $1 \%$ of the married couples were mixed ethnic involving a minority and a White individual.

We extracted a range of individual-level explanatory variables from the 1991 census that would be expected to relate to divorce risk (Table 2). Age at marriage and duration of marriage are important predictors of union dissolution. As the LS does not have data on age at marriage we use the age at 1991 as a proxy for these two factors. We included educational qualifications in 1991 in two categories: with and without a degree. Economic activity in 1991 was also included in four categories: in employment, unemployed, retired, and economically inactive. In addition, we distinguished LS members who were born in the UK from those born outside the UK. It is important to include characteristics of both partners (Gaines et al. 2005), so we formed combined measures from both partners in couples for age, educational level, country of birth and economic activity. The marital status of unions was defined using the marital status of both partners. We defined the couple as in a first marriage if both of them were in a first marriage, in a second or later marriage if either was re-married. For men in the sample, 95\% were White while South Asians, Blacks and Other Asians accounted for $3.8 \%, 0.9 \%$ and $0.4 \%$ respectively, and $8.5 \%$ of men were born outside the U.K. The distribution of women by ethnic group was similar to that of men. Housing tenure for 1991 was included as the literature suggests that the risk of divorce is higher for renters as divorce is less costly than for homeowners. In addition people in social rented housing have higher risks of divorce due to financial strains. Region of residence is another factor which may be associated with divorce and therefore was included as an explanatory variable.

\section{<Table 2 Characteristics at the 1991 census for members of couples>}

To identify divorces, we started with all LS members living in married couples in 1991 and selected those who were single or had re-partnered by 2001 (different partners were identified based on their dates of birth). Couples where LS members became widowed during the follow-up period were dropped from the analysis (as a result, 15,325 couples were removed from the analysis). We explored the risks of divorce descriptively and we also modelled the probability of divorce using logistic regressions. The dependent variable was partnership status in 2001: couple intact (0), couple dissolved (1). The statistical software we used was STATA 9 (Stata Corp, 2005). As the ONS LS is a quasi-random sample of the population in England and Wales, no weighting was needed in the analysis (Hattersley \& Creeser, 1995).

\section{Results}

Patterns of Mixed-ethnic Marriages

Most men and women lived with a partner from their own ethnic group (Table 3). Other Asian women were the most likely to out-marry (35\%) and Black men were the second most 
likely to be in a mixed ethnic marriage (23\%). Black women also had a high out-marrying rate $(19 \%)$, while both South Asian men (4\%) and women $(2 \%)$ had low rates of outmarrying with Whites. Other Asian men had exogamous marrying rates of 17\%. Black and South Asian men were more likely than Black and South Asian women to partner with a White person, while Other Asians women were more likely than men to have a White partner.

\section{<Table 3 Percentage of ethnic minority members of couples living with a White partner by gender and 1991 Census characteristics>}

The out-marrying rates varied by the demographic and socio-economic characteristics of the minority group member of the couple. In general, out-marrying was more common for younger adults; the proportion in mixed ethnic unions with White people in the youngest age group was generally close to double that for the oldest age group. The only exception was South Asian men, where there was no evidence of any age trend.

The percentage of out-marrying with Whites was much higher for ethnic minority men and women who were born in the UK compared to those who were born abroad. For all ethnic-gender groups, the rate of out-marrying for the UK born was roughly twice that for those born outside the UK. For all groups, except Black men, those with higher qualifications were considerably more likely to marry Whites than those with no degree; for South Asian men and women, those with degrees were around four times as likely as those without degrees to marry a White person, with around one in ten South Asians marrying a White person.

\section{Analysing the risk of divorce}

Table 4 gives the number of marriages in 1991 and the number and proportion divorced by 2001 by ethnic group. The overall average divorce rate of $12 \%$ is dominated by that of White co-ethnic marriages, the largest population group. Marriages involving Black people had higher rates of divorce with the rate of divorce for Black co-ethnic couples and for BlackWhite couples being over 20\%. South Asian and Other Asian co-ethnic couples exhibited lower divorce rates than White-White couples. South Asian-White couples had higher rates of divorce than both White-White and South Asian-South Asian couples. The same pattern is evident for Other Asian-White couples who had higher rates of divorce than both WhiteWhite and Other Asian-Other Asian couples. From these descriptive figures it appears that mixed ethnic unions do demonstrate higher risks of divorce than co-ethnic unions.

\section{< Table 4 Number of spousal couples in 1991 and proportion of divorced by 2001>}

We fitted logistic regression models to examine the likelihood of divorce by couple type. Model 1 in Table 5 compares the risk of divorce by the ethnic composition of the couple, with no adjustment for other factors. Model 2 shows the risk of divorce controlling for a range of factors which may contribute to the risk of divorce. From Model 1, which is entirely based on information from Table 4, we can see that unions involving Black people had higher risks of divorce in comparison with the risk for White-White couples. Black-White couples had the highest odds ratio of divorce, more than twice the risk for White-White couples and higher than the risk of divorce for Black-Black couples. While the risk of divorce for South Asian co-ethnic marriages was lower than that for White-White couples, the risk of divorce for South Asian-White couples was no different from that for White-White couples. Marriages involving Other Asians showed similar risks of divorce to White co-ethnic unions. To assess the risks of divorce for mixed ethnic unions, these risks need to be compared to the risks of divorce for co-ethnic couples of both the ethnic groups which constitute the mixed 
couple types. Therefore, apart from comparing the odds ratio of divorce for ethnic groups with that for the reference White co-ethnic couples, we also compared risks of divorce for mixed ethnic unions with that for the constituent minority co-ethnic unions. We can see that Black-White mixed ethnic unions had significantly higher divorce risks than Black-Black couples. We also see that South Asian-White couples had higher risks of divorce than South Asian co-ethnic couples. Other Asian mixed ethnic unions did not have higher risks than Other Asian co-ethnic unions. Therefore, in a model where we did not control for any demographic and socio-economic factors, we found a heterogamy effect (which posits that the risk of divorce for mixed ethnic unions is higher than the risk of divorce for corresponding origin groups) only for mixed ethnic marriages involving Blacks.

In Model 2 we included a range of control variables. We first discuss the effects of demographic and socio-economic characteristics on the likelihood of divorce. In comparison to couples with both in the youngest age group (16-34), older couples had a reduced risk of divorce, down by roughly $80 \%$ for couples where both were in the oldest group (50+). Where couples fell in different age groups the rates were generally intermediate between those for both members at each individual age. The exception was men in the youngest age group married to women in the oldest who had the highest rate of divorce. In comparison with couples where neither partner held a degree, other types of couple were less likely to divorce, with couples where both partners held a degree being the least likely to end up in divorce by 2001. Compared with couples with both partners in employment, all other combinations appeared to raise the likelihood of divorce, apart from couples where the male partner was employed and female partner was economically inactive. Country of birth was also found to be an important factor in understanding divorce. Couples where at least one of the partners was born outside the UK had elevated risks of divorce. In terms of marital status, those in second or later marriages had a higher risk of divorce than those in first marriages. Couples with children had higher divorce risks than couples without children, especially when there was more than one child in the family and when the children were older than 4 . This is an unexpected result which is the opposite of what would be expected based on most existing literature (Svarer and Verner, 2008). However, Chan and Halpin (2003) found similar results using data from the British Household Panel Survey (BHPS). To test whether our estimates of risks of divorce on union types were robust to the inclusion or exclusion of the children variable, we investigated models without it. The odds ratios of divorce for union types remained largely unchanged (modelling results are available upon request). Thus we have retained this variable in the model. However, we acknowledge that the effect of children on stability of marriage needs further research as couples with large families are a highly selected group (Svarer and Verner, 2008). Social renters and private renters had higher risks of divorce than homeowners. We also found regional variation in the risks of divorce: living in Southern England was associated with higher divorce risks compared with living in North East and Yorkshire and the Humberside.

Introduction of demographic and socio-economic variables into the regression had a considerable attenuation effect on the ethnic group parameters. Odds ratios of divorce for Black-White couples are now only 52\% higher than the risk of divorce for White-White couples. So more than half of the higher risk as found in model 1, can be explained by demographic and socio-economic characteristics of these couples. The attenuation effect is similar for mixed marriages between Whites and South Asians but to a lesser degree with about $30 \%$ of the risk of divorce being attributed to demographic and socio-economic characteristics of couples. Attenuation is also seen for unions involving Other Asians. The odds ratio of divorce for Other Asian co-ethnic marriages was reduced by about $30 \%$ and became significantly lower than the risk for White-White couples. In Model 2, mixed ethnic unions involving Black people did not show elevated or reduced risks of divorce compared to 
Black-Black unions. Mixed ethnic marriages involving White and South Asian people appeared to have higher risks of divorce than South Asian-South Asian couples. For Other Asian mixed ethnic marriages the likelihood of divorce was not significantly different from that for Other Asian co-ethnic marriages.

In summary, much of the higher risks of divorce in mixed ethnic marriages involving Blacks and South Asians can be explained by their different demographic and socioeconomic characteristics, with the main factor being their younger age structure. For example, $41 \%$ of Blacks in mixed ethnic marriages were in the youngest 16-34 age group while the corresponding percentage for co-ethnic marriages was $27 \%$. To get more insight into the relative contribution of each control variable to the fit of the model we ran a series of regressions which included couple type and only one of the controls. This exercise showed that while economic activity, tenure, and education were all significant predictors of divorce risks, the age of couples, which included a combination of both male and female ages, had the largest effect on the reduction of odds ratios of couple types. These model results can be requested from the author. The conclusion from Table 5 is that the heterogamy effect involving Whites and Blacks which was present in Model 1 disappeared in Model 2.

\section{<Table 5 odds ratios of marital dissolution, results from logistic regression >}

Finally, we also investigated whether the risks of divorce varied between gender combinations of mixed ethnic marriages. We repeated the regressions from Table 5, but added gender into the equation by breaking down the mixed ethnic marriages by ethnic and gender type. Here we only present the full model which includes all demographic and socioeconomic variables. Because the effects of these control variables were similar to what was found in model 2 of Table 5, we only present the odds ratios by couple type. From the overlapping confidence intervals in Table 6 we can see that there was no case where the divorce rates for White-ethnic minority couples differed by their gender mix. For BlackWhite couples the rates by gender mix are very close. For South-Asian-White couples the divorce rate is higher when the male is White, whereas for Other-Asian-White it is higher when the female is White.

\section{<Table 6 Odds ratios of marital dissolution by ethnic-gender group, results from logistic regression>}

\section{Conclusion}

In this paper we used the ONS-LS data to examine the 10-year (1991-2001) risk of marital dissolution for mixed ethnic unions compared with co-ethnic unions. This large and representative dataset provided the opportunity to explore patterns of divorce for mixed ethnic unions, something which is not possible due to small number problems, when using other surveys such as the British Household Panel Survey (BHPS). The ONS-LS dataset also allowed us to control for a number of variables, which are difficult to obtain from traditional marriage and divorce registration data (Kalmijn et al. 2005). As pointed out by Orbuch et al (2002), ethnicity may serve as a proxy for other socioeconomic variables such as income and education and it is therefore important to control for as many variables as possible to tease out the real ethnicity effect. We used information such as educational qualifications, economic activity, housing tenure to explore whether the factors in 1991 predicted the likelihood of divorce by 2001. This overcomes the problem of reverse causality that can occur when people's socio-economic conditions change after divorce. 
Our results for the risk of marital dissolution demonstrate considerable variation between ethnic groups, although these differences are much reduced when adjusted for other characteristics, especially the age profiles of the different ethnic groups. Mixed-ethnic unions appear to have a risk of divorce which is close to the higher risk found for the two constituent co-ethnic unions. The results do not support the heterogamy model which posits that the risk of divorce for mixed ethnic unions is higher than the risk of divorce for the corresponding origin groups. Instead our results support the convergence model: the likelihood of divorce of mixed ethnic unions falls between the higher and the lower risk showed by the component origin ethnic groups. That the risk for mixed ethnic unions is close to the higher risk of the two origin groups may be attributable to the process of divorce. The spouse who comes from the ethnic group with a more tolerant attitude toward divorce is likely to be more proactive in the process of divorce. When there is a conflict between two partners the partner with a higher risk might propose divorce as one solution to the marriage and thus initiate the separation and divorce process. This is particularly relevant in the Western marriage legal system where a no-fault case is accepted as the basis for divorce. A partner can unilaterally demand to end the partnership without the consent of the other partner. This could result in the divorce rate for mixed-ethnic couples taking on the maximum for the corresponding coethnic rates. A study of the divorce process, particularly within a mixed ethnic setting might throw more light on this interpretation of our results.

Although we used a unique and very rich dataset, we acknowledge that the data we used has some limitations. Despite the very large ONS-LS sample, our models included relatively small numbers of mixed ethnic marriages. As a result some caution should be exercised in interpreting the results. Also, the data did not include information on age at the formation of marriage, or on the duration of marriage, both of which have previously been shown to be associated with risks of divorce. If different couple types (by ethnic composition) also show different patterns in the age at marriage, this might explain some of the effects found in this study. However, this would need further investigation. In this study we controlled for age of both couples in 1991. This has at least partly accounted for the effect of age at marriage. This is because overall age at marriage and age for couples in 1991 should be correlated. Young couples are definitely those who are married at a young age and also have shorter durations of marriage. The situation for older people is more complicated. For example, older people could have married at an older age and thus have shorter marriage durations. Nevertheless, a large proportion of older people will have married at a relatively young age and have fairly long durations.

The BHPS is a panel dataset which provides age at marriage and duration of marriage. However, the BHPS has about 10,000 sample members and the number of people involved in mixed ethnic unions is too small for a statistical analysis. Another issue which is likely to influence the outcomes of this study is that those in a mixed-ethnic union are a selected category of people, defined by characteristics which were not measured in the Census. However, the direction of bias caused by these omitted variables is not clear. If people who are involved in mixed ethnic unions are more likely to take risks, and are also more likely to break up when their partnership encounters problems, our results are upwardly biased. If the unmeasured characteristics make people in mixed ethnic unions strongly committed to overcome any differences between partners (Janssen 2002), our estimates are too conservative. Overall, our results should be interpreted with caution and better regarded as an analysis of determinants of who divorces as opposed to an analysis of what conditions result in divorce.

Although mixed ethnic unions have drawn scholarly interest for a long time, most research has been on the formation of mixed ethnic unions. In contrast, studies on the stability of mixed ethnic unions are scarce, and were mainly conducted in the U.S (Bratter 
and King 2008; Zhang and van Hook 2009). This research has filled a gap in our knowledge of mixed ethnic marriages in Britain by examining the risk of divorce for mixed ethnic couples; this has not been studied to date. Our results differ from a previous study where cross-nation partnerships in the Netherlands were found to display strong heterogamy for risks of divorce (Kalmijn et al. 2005). Our results support the ethnic convergence theory where the risk of divorce for mixed ethnic marriages falls between the higher and the lower risk for the two constituent ethnic groups. Further studies are needed to understand how values and traditions of ethnic groups, and differences in attitudes towards divorce, influence individuals who out-partner in their decisions when dealing with problems in their relationships.

\section{Acknowledgments}

This research is funded by the ESRC under the Understanding Population Trends and Processes (UPTAP) programme (Award Ref: RES-163-25-0045). The permission of the Office for National Statistics to use the Longitudinal Study is gratefully acknowledged, as is the help provided by the Centre for Longitudinal Study Information \& User Support (CeLSIUS), particularly Rachel Stuchbury and Julian Buxton. CeLSIUS is supported by the ESRC Census of Population Programme (Award Ref: RES-348-25-0004). The data from ONS is Crown copyright and reproduced with the permission of the controller of HMSO and Queen's Printer for Scotland. This study uses research datasets which may not exactly reproduce National Statistics aggregates. The authors alone are responsible for the interpretation of the data.

\section{References}

Ballard, R. (1997). Negotiating race and ethnicity: exploring the implications of the 1991 Census. Patterns of Prejudice, 30, 3-33.

Berthoud, R. (2000). Family formation in multi-cultural Britain: three patterns of diversity. Institute for Social and Economic Research Working Paper 2000-34. University of Essex.

Becker, G. S. (1981). A treatise on the family, Cambridge: Harvard University Press.

Benson, S. (1981). Ambiguous ethnicity: interracial families in London, Cambridge: Cambridge University Press.

Berrington, A. (1996). Marriage patterns and inter-ethnic unions. In D. Coleman \& J. Salt (Eds.), Ethnicity in 1991 census, volume one, Demographic characteristics of the ethnic minority populations (pp. 178-212). London: HMSO.

Blau, P. M., \& Schwartz J.E. (1984). Crosscutting social circles: testing a macrostructural theory of intergroup relations. Orlando: Academic Press.

Bratter, J. F., \& King, R. B. (2008). "But will it last?' : Marital instability for interracial and same-race couples. Family Relations, 57(2), 160-171.

Bumpass, L. L., \& Sweet J. A. (1972). Differentials in marital instability: 1970. American Sociological Review, 37(6), 754-766.

Chan, T. W., \& Halpin. B. (2003). Union dissolution in the United Kingdom. International Journal of Sociology, 32(4), 76-93.

Coleman, D. (1985). Ethnic intermarriage in Great Britain. Population Trends, 40, 4-10.

Coleman, D. (2004). Partner choice and the growth of ethnic minority populations. Bevolking en Gezin, 33(2), 7-34.

Coleman, D. (2009). Divergent patterns in the ethnic transformation of societies. Population and Development Review, 35(3), $449-478$. 
Cuningham, S. A. (1990). Interracial marriage and divorce for Blacks and Whites in the United States. Papers presented at the Annual Meeting of the Southern Demographic Association, Louisville, Kentucky, 18-20 October.

Data Management and Analysis Group Update (2005). Inter-ethnic unions, DMAG.

Dribe, M., \& Lundh, C. (2011). Intermarriage, value context and union dissolution: Sweden 1990-2005. European Journal of Population. DOI 10.1007/s10680-011-9253-y

Ellis, M., Wright, R., \& Parks, V. (2004). Work together, live Apart? Geographies of racial and ethnic segregation at home and at work. Annals of the Association of American Geographers, 94(3), 620-637.

Feng, Z., Boyle, P., van Ham, M., \& Raab G. (2010). Neighbourhood ethnic mix and the formation of mixed ethnic unions in Britain. In J. Stillwell \& M. van Ham (Eds.) Ethnicity and integration, Understanding population trends and processes 3 ( $\mathrm{pp} 83$ 104). Heidelberg: Springer.

Finney, N., \& Simpson, L. (2003). 'Sleepwalking to segregation'? Challenging myths about race and migration. Bristol: The Policy Press.

$\mathrm{Fu}, \mathrm{X}$. (2006). Impact of socioeconomic status on inter-racial mate selection and divorce. The Social Science Journal, 43(2), 239-258.

Gaines, S.O., Jr. Gurung, R. A. R., Lin, Y. Y., \& Pouli, N. (2006). Interethnic relationships. In J. Feeney \& P. Noller (Eds.) Close Relationships: Functions, Forms, and Processes (pp. 171-187). New York: Psychology Press.

Hattersley, L., \& Creeser, R. (1995). The longitudinal study, 1971-1991: history, organisation and quality of data. London: Office of Population Censuses and Surveys.

Heaton, T. B., \& Albrecht, S. L. (1991). Stable unhappy marriages. Journal of Marriage and Family, 53(3), 747-758.

Heaton, T. B. (2002). Factors contributing to increasing marital stability in the United States, Journal of Family and Issues, 23(3), 392-409.

Holdsworth, C., \& Dale, A. (1997). Issues in the analysis of ethnicity in the 1991 British census. Ethnic and Racial Studies, 20(1), 160-180.

Houston, S., Wright, R., Ellis, M., Holloway, S. R., \& Hudson, M. (2005). Places of possibility: where mixed race partners meet. Progress in Human Geography, 29(6), 700-717.

Janssen, J. P. G. (2002). Do opposites attract divorce? Dimensions of mixed marriage and the risk of divorce in The Netherlands. Doctoral Dissertation. Department of Sociology, University of Nijmegen, The Netherlands.

Johnston, R., Poulsen, M., \& Forrest, J. (2006). Ethnic residential segregation and assimilation in British towns and cities: A comparison of those claiming single and dual ethnic identities. Migration Letters, 3(1), 11-30.

Jones, F. L. (1994). Are marriages that cross ethnic boundaries more likely to end in divorce? Journal of Population Research, 11(2), 115-132.

Jones F. L. (1996). Convergence and Divergence in Ethnic Divorce Patterns: A Research Note. Journal of Marriage and the Family, 58(1), 213-218.

Kalmijn, M. (1991). Shifting boundaries: trends in religious and educational homogamy. American Sociological Review, 56(6), 786-800.

Kalmijn, M. (1998). Intermarriage and homogamy: causes, patterns, trends, Annual Review of Sociology, 24, 395-421.

Kalmijn, M., de Graaf, P.M., \& Janssen, P.G. (2005). Intermarriage and the risk of divorce in the Netherlands: The effects of differences in religion and in nationality, 1974-94. Population Studies, 59(1), 71-85.

Kiernan K., \& Mueller, G. (1999). Who divorces? In S. McRae (Ed.) Changing Britain: Families and household in the 1990s (pp. 377-403). Oxford: Oxford University Press. 
Maneker, J. S., \& Rankin, R. P. (1988). Correlates of marital duration and Black-White intermarriage in California. Journal of Divorce, 11(2), 51-67.

Model, S., \& Fisher, G. (2002). Unions between blacks and whites: England and the US compared. Ethnic and Racial Studies, 25(2), 728-754.

Monahan, T. P. (1970). Are interracial marriages really less stable? Social Forces, 48(4), 461-473.

Muttarak, R. (2003). Who intermarries in Britain? MSc Thesis, Department of Sociology, University of Oxford.

Muttarak, R. (2004). Marital assimilation: interethnic marriage in Britain, Population and society: issues, research, policy, $12^{\text {th }}$ Biennial Conference of Australian Population Association, 15-17 September 2004, Canberra, Australia.

Orbuch, T. L., Veroff, J., Hassan, H., \& Horrocks, J. (2002). Who will divorce: A 14-year longitudinal study of black and white couples. Journal of Social and Personal Relationships, 19(2), 179-202.

Rees, P, \& F. Butt (2004). Ethnic change and diversity in England, 1981-2001. Area, 36(2), 174-186.

Schoen, R. \& Cohen, L.E. (1980). Ethnic endogamy among Mexican American grooms: a reanalysis of generational and occupational effects. American Journal of Sociology, 86(2), 359-366.

Schoen, R., \& Weinick, R. M. (1993). Partner choice in marriages and cohabitations. Journal of Marriage and Family, 55(2), 408-414.

Schwertfeger, M. M. (1982). Interethnic marriage and divorce in Hawaii: A panel study of 1968 first marriages. Marriage and Family Review, 5(1), 49-59.

Stata Corp. 2005 Stata statistical software: Release 9.0. College Station, TX: Stata Corporation

Svarer, M., \& Verner, M. (2008). Do children stabilize relationships in Denmark? Journal of Population Economics 21(2), 395-417

Teachman, J. D. (2002). Stability across cohorts in divorce risk factors. Demography, 39(2), 331-351.

Thornton, A. (1989). Changing attitudes toward family issues in the United States. Journal of Marriage and the Family, 51(4), 873-893.

Tolsma, J., Lubbers, M., \& Coenders, M. (2008). Ethnic competition and opposition to ethnic intermarriage in the Netherlands: a multi-level approach. European Sociological Review, 24(2), 215-230.

Trent, K., \& South, S. J. (1989). Structural determinants of the divorce rate: A cross-societal analysis. Journal of Marriage and Family, 51(2), 391-404.

Tribalat, M. (1987). Divorce des couples mixtes in RFA. Population, 42(1), 161-6.

van Ham, M., \& Tammaru, T. (2011). Ethnic Minority-Majority Unions in Estonia. European Journal of Population. 27(2) 313-335

Zhang, Y., \& van Hook, J. (2009). Marital dissolution among interracial couples. Journal of Marriage and Family, 71(1), 95-107. 
Table 1 Ethnic definition in the 1991 census

\begin{tabular}{ll}
\hline $\begin{array}{l}\text { Ethnic group categories used } \\
\text { in the analysis }\end{array}$ & Ethnic groups identified in the 1991 census \\
\hline White & White \\
Black & Black-Caribbean \\
& Black-African \\
& Black other \\
& Black and White \\
& Indian \\
South Asian & Pakistani \\
& Bangladeshi \\
& Chinese \\
Other Asian & Other Asian \\
& Other ethnic group: non-mixed origin \\
Other* & Other ethnic group: mixed origin \\
\hline
\end{tabular}

Source: ONS-LS

* This group was dropped from the subsequent analysis due to its small size and heterogeneous membership 
Table 2 Characteristics at the 1991 Census for members of the 172,473 couples (\%)

\begin{tabular}{|c|c|c|c|}
\hline Variable & Category & Male partner & Female partner \\
\hline \multirow[t]{4}{*}{ Ethnicity } & White & 94.9 & 94.9 \\
\hline & Black & 0.9 & 0.8 \\
\hline & South Asian & 3.8 & 3.7 \\
\hline & Other Asian & 0.4 & 0.5 \\
\hline \multirow[t]{3}{*}{ Age } & $16-34$ & 21.8 & 28.2 \\
\hline & $35-49$ & 40.2 & 40.4 \\
\hline & $50+$ & 38.0 & 31.4 \\
\hline \multirow[t]{2}{*}{ Country of birth } & In the UK & 8.5 & 8.7 \\
\hline & Outside UK & 91.5 & 91.3 \\
\hline \multirow[t]{4}{*}{ Economic activity } & Employed/self-employed & 79.3 & 58.7 \\
\hline & Unemployed & 5.4 & 2.1 \\
\hline & Retired & 10.7 & 7.9 \\
\hline & Inactive & 4.6 & 31.3 \\
\hline \multirow[t]{2}{*}{ Education } & No Degree & 88.8 & 94.9 \\
\hline & Degree and Higher & 11.2 & 5.1 \\
\hline \multirow[t]{2}{*}{ Marital status } & First marriage(both partners) & & 83.3 \\
\hline & $\begin{array}{l}\text { Later marriage (either } \\
\text { partner) }\end{array}$ & & 16.7 \\
\hline \multirow[t]{3}{*}{ Housing tenure } & Owned & & 85.5 \\
\hline & Social & & 11.8 \\
\hline & Rent & & 2.7 \\
\hline \multirow[t]{4}{*}{$\begin{array}{l}\text { Number of } \\
\text { children in family }\end{array}$} & 0 & & 51.2 \\
\hline & 1 & & 18.3 \\
\hline & 2 & & 21.4 \\
\hline & 3 and above & & 9.0 \\
\hline \multirow[t]{2}{*}{$\begin{array}{l}\text { Presence of } \\
\text { children under } 5\end{array}$} & No & & 79.8 \\
\hline & Yes & & 20.2 \\
\hline \multirow{6}{*}{$\begin{array}{l}\text { Geographical } \\
\text { region }\end{array}$} & North East /Yorkshire \& & & \\
\hline & Humberside & & 15.2 \\
\hline & North West /Wales & & 18.9 \\
\hline & Midlands & & 19.4 \\
\hline & South & & 36.3 \\
\hline & London & & 10.2 \\
\hline
\end{tabular}

Source: ONS-LS, authors' calculations 
Table 3 Ethnic minority members of couples, total numbers and percentages living with a White partner, by gender and 1991 Census characteristics

\begin{tabular}{|c|c|c|c|c|c|c|c|c|c|c|c|c|c|c|c|}
\hline \multirow[b]{3}{*}{ Males } & & & \multicolumn{3}{|c|}{ Age group } & \multicolumn{4}{|c|}{ Marital status } & \multicolumn{2}{|c|}{ Place of birth } & \multicolumn{4}{|c|}{ Education } \\
\hline & \multicolumn{2}{|c|}{ All } & $16-34$ & $35-49$ & $50+$ & \multicolumn{2}{|c|}{$\begin{array}{c}\text { First } \\
\text { marriage }\end{array}$} & \multicolumn{2}{|c|}{$\begin{array}{c}\text { later } \\
\text { marriage }\end{array}$} & Not UK & UK & \multicolumn{2}{|c|}{ No degree } & \multicolumn{2}{|c|}{$\begin{array}{c}\text { With } \\
\text { degree }\end{array}$} \\
\hline & $\mathrm{N}$ & $\%$ & $\%$ & $\mathrm{~N} \%$ & $\%$ & $\mathrm{~N}$ & $\%$ & $\mathrm{~N}$ & $\%$ & $\%$ & $\%$ & $\mathrm{~N}$ & $\%$ & $\mathrm{~N}$ & $\%$ \\
\hline Black & 1505 & 23.1 & 36134.1 & 53224.4 & 61215.4 & 1260 & 20.3 & 245 & 37.1 & 125217.5 & 25350.6 & 1354 & 23.5 & 151 & 19.2 \\
\hline South Asian & 6550 & 3.9 & $1893 \quad 3.5$ & $2801 \quad 3.5$ & $1856 \quad 5.0$ & 6166 & 3.5 & 384 & 10.9 & $6261 \quad 3.9$ & $289 \quad 5.5$ & 5837 & 3.1 & 713 & 10.9 \\
\hline Other Asian & 654 & 16.9 & 16622.9 & 31516.2 & 17312.7 & 608 & 16 & 46 & 30.4 & 63616.0 & 1850.0 & 553 & 14.5 & 101 & 30.7 \\
\hline \multicolumn{16}{|l|}{ Females } \\
\hline Black & 1420 & 18.5 & 68127.3 & 55420.4 & $358 \quad 6.7$ & 1197 & 16.1 & 223 & 30.9 & 110312.9 & 31737.8 & 1344 & 17.9 & 76 & 28.9 \\
\hline South Asian & 6427 & 2.1 & $2872 \quad 3.2$ & 27151.92 & $905 \quad 1.6$ & 6052 & 1.7 & 375 & 8.8 & $5970 \quad 1.9$ & $457 \quad 4.8$ & 6194 & 1.8 & 233 & 10.7 \\
\hline Other Asian & 839 & 35.3 & 35343.6 & 38833.8 & 11923.5 & 729 & 29.9 & 110 & 70.9 & 82134.6 & 1866.7 & 782 & 34.1 & 57 & 50.9 \\
\hline
\end{tabular}

Source: ONS-LS, authors' calculations 
Table 4 Number of spousal couples in 1991 and proportion of divorced by 2001

\begin{tabular}{lrrr}
\hline Union type & $\begin{array}{r}\text { Number of } \\
\text { couples }\end{array}$ & $\begin{array}{rrr}\text { Number of } \\
\text { divorced }\end{array}$ & \% divorced \\
\hline White - White & 143,126 & 19,945 & 12.2 \\
Black - Black & 924 & 234 & 20.2 \\
Black - White & 463 & 146 & 23.9 \\
South Asian - South Asian & 5,599 & 693 & 11.0 \\
South Asian - White & 335 & 58 & 14.8 \\
Other Asian - Other Asian & 481 & 62 & 11.4 \\
Other Asian - White & 349 & 58 & 14.3 \\
Total & 151,277 & 21,196 & 12.3 \\
\hline
\end{tabular}


Table 5 Odds ratios of union dissolution between 1991 and 2001, results from logistic regression

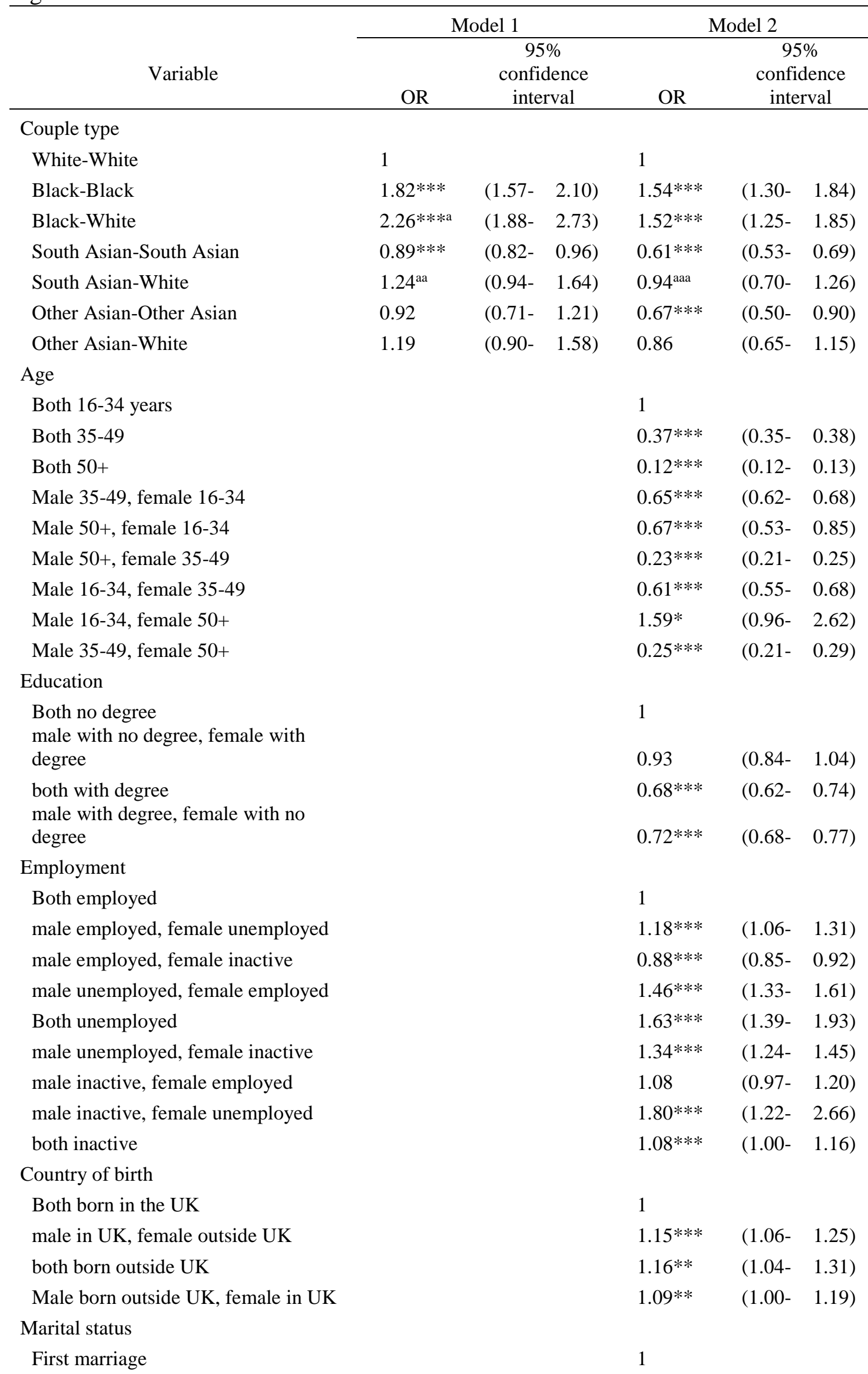


Second marriage

$1.72 * * * \quad 1.65-\quad 1.78)$

Number of children

0

1

1

$1.17 * * * \quad(1.12-\quad 1.23)$

2

$1.22 * * * \quad(1.17-1.28)$

3

$1.34 * * * \quad(1.26-1.42)$

Children under 5

No

1

Yes

$0.86 * * * \quad(0.82-\quad 0.90)$

Tenure

Owned

1

social rent

$1.32 * * * \quad(1.27-1.38)$

private rent

$1.47 * * * \quad(1.36-1.59)$

Region

North East

1

North West

$0.95 * \quad(0.90-1.00)$

Midlands

$1.00 \quad(0.95-1.05)$

South

$1.05^{* *} \quad(1.01-1.10)$

London

$1.00 \quad(0.94-\quad 1.06)$

$* \mathrm{p}<0.1, * * \mathrm{p}<0.05, * * * \mathrm{p}<0.01$ (significantly different from the reference group) ${ }^{a} \mathrm{p}<0.1{ }^{\text {aa }} \mathrm{p}<0.05$, ${ }^{\text {aaa }} \mathrm{p}<0.01$ (significantly different from minority co-ethnic unions)

Source: ONS-LS, authors' calculations 
Table 6 Odds ratios of union dissolution by ethnic-gender group between 1991 and 2001, results from logistic regression

\begin{tabular}{llll}
\multicolumn{1}{c}{ Variable } & \multicolumn{2}{c}{$95 \%$} \\
& \multicolumn{1}{c}{ OR } & $\begin{array}{c}\text { confidence } \\
\text { interval }\end{array}$ \\
\hline Union type & & & \\
$\quad$ White-White & 1 & & \\
Black-Black & $1.54^{* * * *}$ & $(1.30-$ & $1.84)$ \\
Black male - White female & $1.53^{* * *}$ & $(1.18-$ & $1.99)$ \\
White male - Black female & $1.50^{* * * *}$ & $(1.12-$ & $2.02)$ \\
South Asian - South Asian & $0.61^{* * * *}$ & $(0.53-$ & $0.69)$ \\
South Asian male - White female & 0.79 & $(0.53-$ & $1.18)$ \\
White male - South Asian female & $1.19^{\text {aaa }}$ & $(0.77-$ & $1.84)$ \\
Other Asian - Other Asian & $0.67^{* * *}$ & $(0.50-$ & $0.90)$ \\
Other Asian male - White female & $1.14^{\mathrm{a}}$ & $(0.68-$ & $1.90)$ \\
White male - Other Asian female & 0.77 & $(0.54-$ & $1.10)$ \\
\hline
\end{tabular}

$* \mathrm{p}<0.1, * * \mathrm{p}<0.05, * * * \mathrm{p}<0.01$ (significantly different from the reference group) ${ }^{a} \mathrm{p}<0.1{ }^{\text {aa }} \mathrm{p}<0.05$, aaa $\mathrm{p}<0.01$ (significantly different from minority co-ethnic unions) Source: ONS-LS, authors' calculations 